\title{
Prospective Teachers' Views about Creating Websites for Social Studies Teaching in Distance Education
}

\author{
Canan Akyol ${ }^{1 *}$, Görkem AvcI ${ }^{2}$, Özdemir Dikicigil ${ }^{3}$ \\ ${ }^{1,3}$ Dokuz Eylül University, Buca Faculty of Education, Department of Social Studies Education, İzmir/Turkey \\ ${ }^{2}$ Bartin University, Faculty of Education, Department of Primary Education, Bartin/Turkey
}

\begin{abstract}
The present study aims to investigate prospective teachers' views about creating websites for social studies teaching in distance education. To this end, the study employed the case study method, one of the qualitative research methods. The study group consisted of prospective social studies and classroom teachers studying in the 2019-2020 academic year at the Faculty of Education of a state university located in the Black Sea Region. The study was conducted in two phases: the first phase was carried out with 112 prospective teachers and the second with 12. Data were collected by means of structured and semi-structured interviews and were analyzed by content analysis. Data analysis revealed that websites were a part of the learning-teaching process, that it was important to use websites as educational tools, that websites enabled technology to be integrated into education, that websites enabled the inclusion of up-to-date content for effective teaching of social studies, and that websites provided students with easy access to knowledge through fun learning environments. Based on the results, it can be recommended that the creation and use of websites for the social studies course should be promoted among both working and prospective teachers and that social studies lessons can be taught more effectively with personal educational websites that contain up-to-date, fun, and interactive teaching materials.
\end{abstract}

Keywords: Distance education, website, social studies teaching, prospective teacher.

\section{INTRODUCTION}

In order to fight against the COVID-19 pandemic that emerged in December 2019, states have developed various strategies, while the common strategy has been to control the spread of the virus (WHO, 2020). In this regard, school closures help to break the chain of contamination by providing social distance between people (Germann et al., 2019). More than a billion students worldwide have been affected by the closure of educational institutions due to the pandemic (UNESCO, 2020). In order to ensure the sustainability of education, distance education method has been put into operation. Thus, distance education, which was previously an alternative education method, has emerged as a necessity during the COVID-19 pandemic.

With its nature and content, the social studies course allows the use of digital technologies (Shriner et al., 2010; Demirezen \& Keleş, 2020). Since it is interdisciplinary and contains concrete and abstract concepts from different disciplines, teaching technologies are needed to teach these to students (Dere \& Ateş, 2020). Therefore, in the social studies course, a wide range of technological devices can be used to achieve the gains (Debele \& Plevyak, 2012; Curry \& Cherner, 2016). For these reasons, distance education seems to be quite suitable to the nature and content of social studies teaching.

Parallel to the increasing importance of technology in daily life, the use of technology in education is increasing. National Council for the Social Studies (NCSS, 2013) emphasizes the inevitability of integrating technology into teaching processes to adapt to the digital age. This situation led to the roles of teachers to change as well. Teachers now have to be the one who bring education and technology together in the guiding role (Wright \& Wilson, 2009). Indeed, the Organisation for Economic Co-operation and Development (OECD) underlined that due to this radical change, teachers are now expected to use educational, information, and communication technologies effectively (OECD, 2009). In this respect, it is essential that educators have competence in order for distance education to be successful.

Despite all its negativities, the COVID-19 outbreak is an important opportunity to disseminate technology in education. Indeed, it is predicted that distance education will become the primary educational setting in the near future rather than being an alternative to or a supportive element for face-to-face learning. The experience gained

Corresponding Author e-mail: canan.akyol@deu.edu.tr https://orcid.org/0000-0002-9892-0010

How to cite this article: Akyol C, Avcı G, Dikicigil Ö, (2021). Prospective Teachers' Views about Creating Websites for Social Studies Teaching in Distance Education. Pegem Journal of Education and Instruction, Vol. 11, No. 4, 2021, 9-19

Source of support: Nil

Conflict of interest: None.

DOI: 10.47750/pegegog.11.04.02

Received: 17.04.2021

Accepted: 03.06.2021 Publication: 01.10.2021 
from digital learning, which was put into use immediately during the COVID-19 pandemic, is expected to contribute to the further development of distance education. Thus, in the future, digital learning may become the main educational setting by increasing its functions with the development of new technologies (Telli \& Altun, 2020).

Internet-based teaching tools, which are indispensable for distance education, are widely used in education. Web 2.0 tools increase participation in the lesson by appeal to multiple senses and provide convenience to different types of students, thus contribute significantly to educational processes (Elmas \& Geban, 2012; Horzum, 2007; Prensky, 2001). Many previous researchs discussed the features that web 2.0 tools should have and mentioned the benefits of using them in classes (Gülbahar, 2005; Baş \& Tüzün, 2007; Filiz, Arslan \& Coştu, 2008; Karatepe, Küçükgençay \& Peker, 2020). Prospective teachers also express positive views on distance education (Aytan \& Başal, 2015; Özerbaş \& Akın Mart, 2017; Tatlı, İpek-Akbulut \& Altınışık, 2016; Fırat \& Köksal, 2017). On the other hand, some studies discuss learners' and teachers' various complaints about distance education during the pandemic process (Keskin \& Özer Kaya, 2020; Balaman \& Hanbay Tiryaki, 2021; Karakuş \& Er, 2021). In order to solve the problems in distance education, it is necessary to take advantage of easily accessible, fast, alternative, rich content hosting features of the internet. In this respect, social media sites, virtual classrooms, video sharing sites and web 2.0 tools such as Prezi, Socrative and Kahoot are teaching tools that teachers and prospective teachers are willing to use in distance education (Karaca, 2020; Özer \& Albayrak Özer, 2017; BaltaciGoktalay \& Ozdilek, 2010; Yaylak \& İnan 2018). As can be seen, the number of studies to determine the perceptions and views of teachers and learners on distance education has increased in recent years. Similarly, numerous studies have been conducted to investigate teachers' and prospective teachers' views about technology-supported education. However, the literature does not contain any studies related to the use of websites designed for social studies teaching in the distance education process.

Throughout history, epidemics have posed threats to humanity at intervals. Even in a short span of just two decades in the 21st century, six large-scale epidemics, namely SARS, bird flu, swine flu, MERS, Ebola, and the Zika virus, have occurred. The current COVID-19 pandemic has demonstrated the importance of technological tools and internet-based learning activities (Chick et al., 2020). Therefore, like every member of society, teachers, too, must be prepared for future outbreaks. Hence, the present study is deemed important in that it reveals the possible roles websites can play in social studies teaching in the face of similar challenges that may be encountered in the future and what prospective teachers think about this distance education tool.
Taking these as a starting point, the present study aims to investigate prospective teachers' views about creating websites for social studies teaching in distance education. To this end, answers to the following questions were sought:

\section{What do prospective teachers think about}

1. The usage areas of websites in distance education?

2. The usage areas of websites designed for social studies teaching in distance education?

3. The advantages of using websites designed for social studies teaching in distance education?

4. The disadvantages of using websites designed for social studies teaching in distance education?

5. The content that should be included in websites designed for social studies teaching?

6. The features that websites designed for social studies teaching should have?

7. The effects of creating websites for social studies teaching?

8. The alternatives to websites designed for social studies teaching?

\section{Method}

\section{Research Design}

The present study used the case study method, one of the qualitative research methods, to investigate prospective teachers' views about creating websites for social studies teaching in distance education. A case study is an empirical research method that examines a contemporary phenomenon within its real-life context, especially when the boundaries between the phenomenon and the context are not clearly evident (Yin, 2017, p. 4). Typically, a case study uses question words such as "what", "how" or "why" (Yin, 2017, p. 5). Since the study addresses prospective teachers' views about creating websites for social studies teaching in distance education as a whole (Akar, 2019, p. 164), it specifically employed the holistic single-case study design.

\section{Study Group}

The study group consisted of prospective social studies and classroom teachers studying in the 2019-2020 academic year at the Faculty of Education of a state university located in the Black Sea Region. The first phase of the study enrolled 112 prospective teachers.

As can be inferred from Table 1, the first phase of the study enrolled a total of 112 prospective teachers, of whom

Table 1: Prospective Teachers participating in the First Phase of the Study

\begin{tabular}{|c|c|c|c|}
\hline \multirow[b]{2}{*}{ Department } & \multicolumn{2}{|c|}{ Gender } & \multirow[b]{2}{*}{ Total } \\
\hline & Female & Male & \\
\hline Social Studies Teaching & 40 & 18 & 58 \\
\hline Classroom Teaching & 38 & 16 & 54 \\
\hline Total & 78 & 34 & 112 \\
\hline
\end{tabular}


58 (40 females, 18 males) were studying at the department of "Social Studies Teaching" and 54 (38 females, 16 males) at the department of "Classroom Teaching." Participants of the first phase were determined by criterion sampling, one of the purposive sampling methods. The criterion sampling technique seeks to study all cases that meet a predetermined set of criteria (Yıldırım \& Şimşek, 2011, p. 112). The criterion in this research was having created a website for social studies teaching. Prospective social studies teachers were required to develop websites for the Instructional Technologies course, whereas prospective classroom teachers for the Social Studies Teaching course. The second phase of the study enrolled 12 participants.

As can be inferred from Table 2, the second phase of the study enrolled 12 (six females, six males) prospective teachers studying at the departments of "Social Studies Teaching" and "Classroom Teaching." These twelve participants were selected based on voluntary enrollment from among the participants of the first phase.

\section{Data Collection Instruments and Data Collection}

The study received ethics committee approval at the meeting numbered 18 of the Social and Human Sciences Ethics Committee of the relevant university held on 08.07.2020, with the application number 2020-SBB-0152.

The First Data Collection Instrument: Data were collected in two phases by means of structured and semi-structured interviews. In the first phase, participants' views were collected through Google Forms, an online surveying platform, due to the pandemic. The researchers developed the interview items and revised them based on three experts' feedback with expertise in Turkish education, measurement and assessment, and social studies education. A pilot study was conducted with 14 prospective teachers to test the adequacy of the interview form and to identify possible problems. Since the pilot study revealed no problems, no revisions were made to the interview form following the pilot study. The interview form consisted of two parts: one for personal information and the other for interview items. The personal information part included questions aimed at finding out about the participants' contact information, gender, department, and the link to the websites they created. The form also contained a total of eight interview items. These were aimed at revealing

Table 2:Prospective Teahers participating in the Second Phase of the Study

\begin{tabular}{llll}
\hline & \multicolumn{2}{l}{ Gender } & \\
\cline { 2 - 3 } Department & Female & Male & Total \\
\hline Social Studies Teaching & 3 & 3 & 6 \\
Classroom Teaching & 3 & 3 & 6 \\
Total & 6 & 6 & 12 \\
\hline
\end{tabular}

the participants' views about the usage areas of websites designed for social studies teaching in distance education, the advantages and disadvantages of using websites in online social studies teaching, the content that should be included in websites designed for social studies teaching, the features that websites designed for social studies teaching should have, the effects of creating websites for social studies teaching, and the alternatives to using websites in online social studies teaching.

The Second Data Collection Instrument: In the second phase, online interviews and telephone calls were made with 12 volunteer participants. At this stage, in addition to the interview items, some probing questions were asked to the participants to gain greater insight into their responses. Each interview took 5-10 minutes, and all interviews took 77 minutes in total. The data obtained from the interviews held in the second phase supports and confirms the data obtained from the ones held in the first phase.

\section{Data Analysis}

The data were analyzed by content analysis. Content analysis is a scientific approach that enables investigating a social phenomenon by classifying the message contained in verbal, written, and other materials objectively and systematically in terms of meaning or grammar, converting it into quantitative data and making inferences (Tavşancil \& Aslan, 2001, p. 22). The content analysis seeks to reach the concepts and relationships that can help interpret the obtained data. For this purpose, the obtained data must first be conceptualized and then arranged according to the emerging concepts, and the themes interpreting the data must be identified (Yildırım \& Şimşek, 2011, p. 227). In the analysis of the data, codes such as "T1, F" (Prospective Teacher 1, Female), "T2, M" (Prospective Teacher 2, Male) were assigned to the participants. The responses of the participants to the interview items were examined and coded. The codes were then grouped according to their similarities and differences to identify themes. Later, the determined themes were presented in tables and interpreted.

To ensure validity, excerpts from interviews are provided under the theme tables. The data triangulation method was used to confirm the data obtained in the study. For this purpose, structured interviews were held through the online surveying platform, and semi-structured interviews were held through the video conferencing platform and telephone calls. Also, the process of data analysis is clearly stated.

To ensure reliability, the same interview form was applied to each participant, and the interview items were asked with a similar approach. The raw data and the encodings made during the analysis process are still kept by the researcher. The researchers independently created the codes and themes and then compared them. Following this comparison, the numbers of "consensus" and "dissensus" were determined. 
Using the formula proposed by Miles and Huberman (2016, p. 64) (reliability=consensus/consensus+dissensus), the reliability of the research was calculated for each item. Miles and Huberman stated that a study is considered reliable when the agreement percentage is $70 \%$ and above. Accordingly, since the agreement percentage was calculated as $78 \%$ for the first item, $80 \%$ for the second item, $82 \%$ for the third item, $88 \%$ for the fourth item, $82 \%$ for the fifth item, $84 \%$ for the sixth item, $90 \%$ for the seventh item, and $93 \%$ for the eighth item, and the average agreement percentage for the whole interview form was calculated as $84 \%$, the study was considered reliable.

Regarding ethical considerations, the principles of voluntary participation and confidentiality were observed in the interviews with the participants. The obtained data were not used for purposes other than that of this research. Instead of participants' names, codes were used for each participant while writing the research results.

\section{FINDINGS}

\section{Participants' Views about the Usage Areas of Websites in Distance Education}

As can be inferred from Table 3, usage areas of websites in the teaching process in distance education are "as a part of the learning-teaching process" (f:98), "as supportive educational tools" (f:40), "to provide access to information" (f:25), "to contribute to general competencies for the teaching profession" (f: 22), and "to contribute to social skills" (f: 18) according to the prospective teachers. Accordingly, the most frequently stated usage area was that websites were "a part of the learningteaching process." Some excerpts from participants' responses to the relevant question are as follows:

T60, M: "Topics can be presented on websites in a manner that arouses interest in students. I believe that if images and writing styles can attract students' interest, the teaching process can be carried out more effectively." T22, F: "Personal [educational] websites are used to get more information and to

Table 3: Participants' Views about the Usage Areas of Websites in the Teaching Process.

\begin{tabular}{|c|c|c|c|}
\hline Theme & Codes & $f$ & $\%$ \\
\hline \multirow{6}{*}{$\begin{array}{l}\text { Usage Areas of } \\
\text { Websites in the } \\
\text { Teaching Process }\end{array}$} & $\begin{array}{l}\text { As A Part of the Learning- } \\
\text { Teaching Process }\end{array}$ & 98 & 48.28 \\
\hline & $\begin{array}{l}\text { As Supportive Educational } \\
\text { Tools }\end{array}$ & 40 & 19.70 \\
\hline & $\begin{array}{l}\text { To Provide Access to } \\
\text { Information }\end{array}$ & 25 & 12.32 \\
\hline & $\begin{array}{l}\text { To Contribute to General } \\
\text { Competencies for the } \\
\text { Teaching Profession }\end{array}$ & 22 & 10.83 \\
\hline & To Contribute to Social Skills & 18 & 8.87 \\
\hline & Total & 203 & 100 \\
\hline
\end{tabular}

spread it." T34, M: "Teachers can create personal websites, and depending on the flow of topics in the textbooks, they can provide effective teaching by supporting the topics with videos, images, audios, and activities. They can also be an important support for the education of children who are deprived of school." T17, F: "Personal websites can be used to provide people with useful information, to do various activities, and to show how to use time efficiently." T101, F: "We can use websites for up-to-date information instead of teaching. They can be used to benefit from up-to-date information and lecture notes." T4, F: "As is known, the Internet is the biggest tool for sharing in our age. Since the Internet provides the opportunity to access information in a faster and easier manner and without time constraints, such websites offer students the opportunity to learn the lessons." T58, F: "One thing that I was thinking while creating my own website was to be in contact with students and parents during the distance education process..." T113, F: "They can be used for areas such as personal development, historical awareness, culture." T11, F: "In my opinion, websites can offer materials such as activities, book-movie recommendations, educational games to make efficient use of leisure time in this process." T50, F: “...By sharing various course contents, we get to know resources where individual experiences come to the fore in distance education, which is the future of education."

To sum up, according to the participants, websites provide easy access to information, offer learning activities, support distance education through texts, videos, audios, etc., enable sharing useful information, help convey up-to-date information, strengthen student-teacher interaction, boost personal growth, help make efficient use of leisure time, and can be used effectively to share individual experiences.

\section{Participants' Views about the Usage Areas of Websites Designed for Social Studies Teaching in Distance Education}

As can be inferred from Table 4, usage areas of websites designed for social studies teaching in distance education include, according to the prospective teachers, "use of teaching methods and materials" (f:104), "to contribute to students" (f:45), "to contribute to the development of the field of social studies" (f:31), and "suitability for the social studies curriculum" (f:27). Accordingly, the most frequently stated usage area of websites in social studies teaching was the "use of teaching methods and materials." Some excerpts from participants' responses to the relevant question are as follows:

T25, F: "Activities related to the learning outcomes within the scope of social studies course can be broadcasted here. We can broadcast educational videos or documentaries for students at certain time intervals." T55, F: "I believe that the best way to achieve permanent and effective social studies teaching during distance education is teaching/learning activities; so, we should focus on course-related activities on websites." T49, 
F: "They can be used for students to have fun while learning at a pace depending on their age group. Students' levels should be considered, and course content according to their interests should be included to ensure that they have fun learning." T73, F: "Social studies topics can be related to current issues..." T22, F: "In my opinion, they can be used to spread what has been learned." T96, F: "Information can be given about the importance and topics of the social studies course." T112, F: "We can upload our assignments to the websites, and our teachers can evaluate and grade them (on the website) ..."

To sum up, according to the participants, websites created for social studies teaching can be supported by videos, images, technology, quizzes, games, virtual museums, and teaching activities. They were also of the opinion that websites could be effectively used to ensure that students have fun learning, to teach them current issues, to share information about the social studies course, to provide content suitable for the social studies course, and to perform measurement and assessment.

\section{Participants' Views about the Advantages of Using Websites Designed for Social Studies Teaching in Distance Education}

As can be inferred from Table 5, the advantages of using websites designed for social studies teaching include, according to the prospective teachers, "ensures effective learning" (f:62), "provides practical access to information" (f:60), "improves student motivation" (f:44), "helps students gain knowledge,

Table 4: Participants' Views about the Usage Areas of Websites in Social Studies Teaching.

\begin{tabular}{llll}
\hline Theme & Codes & $f$ & $\%$ \\
\hline $\begin{array}{l}\text { Usage Areas } \\
\text { of Websites in } \\
\text { Social Studies }\end{array}$ & $\begin{array}{l}\text { Use of Teaching Methods and } \\
\text { Teaching }\end{array}$ & $\begin{array}{l}\text { Materials } \\
\text { To Contribute to Students }\end{array}$ & 50.24 \\
& $\begin{array}{l}\text { To Contribute to the development } \\
\text { of the Field of Social Studies }\end{array}$ & 21.74 \\
& $\begin{array}{l}\text { Suitability for the Social Studies } \\
\text { Curriculum }\end{array}$ & 14.98 \\
& Total & 207 & 13.04 \\
& & 27 & \\
\hline
\end{tabular}

skills, and attitudes" (f:23), and "supports personal growth" (f:17). Accordingly, the most frequently stated advantages were "ensures effective learning" and "provides practical access to information.” Some excerpts from participants' responses to the relevant question are as follows:

T10, M: "Students' learning can be supported through videos, images and texts to be included in websites." T50, F: "...we can use a website that talks about history through images or use the website of someone who produces short films and documentaries ..." T33, M: "Both instructional videos and activities will increase the student engagement." T49, F: ... Provides access to information from anywhere with an internet connection, regardless of time and place..." T111, M: "Thanks to websites, people will not waste time visiting different websites to get the right information and will be able to reach immediately the information they want." T58, F: "I think their biggest advantage is that they enable teacher-student interaction during the distance education process ..." T2, M: "Students can have fun learning social studies topics...”T35, F: “...The distance education system is disadvantages may cause problems in education. At this point, I think that the more efficiently teachers integrate technology into education, the better they will reach their students. Personal websites provide many opportunities for teachers to reach their students." T15, F: "We are enriching the content of our website. It is also an advantage for us as prospective teachers." T71, M: "Each of us created a website, taking into account the learning outcomes. I believe creating websites has been a useful experience for us as prospective classroom teachers.” T51, F: “...They can help teachers become aware of students' interests..."

To sum up, according to the participants, using websites designed for social studies teaching offers some advantages such as making available various teaching materials and methods, providing easy and fast access to information, enhancing teacher-student interaction, ensuring that students have fun learning, integrating technology into education, offering rich content, helping prospective teachers gain experience, and helping teachers become aware of their students' interests.

Table 5: Participants' Views about the Advantages of Using Websites in Social Studies Teaching

\begin{tabular}{llll}
\hline Theme & Codes & $f$ & $\%$ \\
\hline Advantages of Websites & Ensures Effective Learning & Ensures Effective Learning & Ensures Effective Learning \\
& Provides Easy Access to & Provides Easy Access to & Provides Easy Access to \\
Information & Information & Improves Student Motivation \\
& Improves Student Motivation & Improves Student Motivation & Helps Students Gain Knowledge, \\
& Helps Students Gain Knowledge, & Helps Students Gain Knowledge, & Skills, and Attitudes \\
& Skills, and Attitudes & Skills, and Attitudes & Supports Personal Growth \\
& Supports Personal Growth & Supports Personal Growth & Total \\
\hline
\end{tabular}




\section{Participants' Views about the Disadvantages of Using Websites Designed for Social Studies Teaching in Distance Education}

As can be inferred from Table 6, the disadvantages of using websites in online social studies teaching include, according to the prospective teachers, "reduces active participation in the learning process" (f:62), "inequality of opportunity" (f:41), "problems in website creation process" (f:30), and "harmful effects of the Internet" (f:23). Accordingly, the most frequently stated disadvantage was "reduces active participation in the learning process." Some excerpts from participants' responses to the relevant question are as follows:

T45, M: "The biggest disadvantage of distance education is surely the lack of face-to-face settings. You cannot see the face or facial expressions, gestures, and feelings of the other person. Thus, you cannot empathize with the other person or take into account their reactions while teaching them. Since the social studies course is about daily life, social life, and personality, it is important for each student to relate this lesson to their personal and social life. However, achieving this in distance education is quite challenging." T26, M: "Failure to provide instant feedback ..." T87, F: "It is possible that every student may not have internet access, tablets, or computers. This causes inequality of opportunity in education..."T28, F: “The necessity to confirm the accuracy of the information they contain." T35, F: “...from teachers' points of view, although creating a website looks easy, it becomes challenging when you want to create a detailed one (since in most websites, it is necessary to use ready-made templates)." T30, F: “...It is very risky in terms of security. Malicious software developers know the codes in these systems very well. For this reason, you are very likely to be hacked ...” T20, M: “...You may find yourself wasting your time on irrelevant websites..."

To sum up, according to the participants, using websites designed for social studies teaching has some disadvantages such as lack of face-to-face settings, failure to provide instant feedback, lack of internet access, tablets, or smartphones, the constant necessity to confirm the accuracy of the information they contain, difficulty in creating websites, security risks, and harmful effects of the Internet.

Table 6: Participants' Views about the Disadvantages of Using Websites in Social Studies Teaching

\begin{tabular}{llll}
\hline Theme & Codes & $f$ & $\%$ \\
\hline $\begin{array}{l}\text { Disadvantages of } \\
\text { Websites }\end{array}$ & $\begin{array}{l}\text { Reduces Active Participation in the } \\
\text { Learning Process }\end{array}$ & 39.74 \\
& $\begin{array}{l}\text { Inequality of Opportunity } \\
\text { Problems in Website Development }\end{array}$ & 41 & 26.29 \\
& Process & & \\
& Harmful Effects of the Internet & 23 & 14.74 \\
& Total & 156 & 100 \\
\hline
\end{tabular}

\section{Participants' Views about the Content to be included in Websites Designed for Social Studies Teaching}

As can be inferred from Table 7, the content to be included in websites designed for social studies teaching, according to the prospective teachers, are "teaching methods and materials" (f:126), "social studies-related topics" (f:75), "culture-related topics" (f:53), "social studies course curriculum" (f:43), and "description of the website" (f:20). Accordingly, the most frequently stated content was "teaching methods and materials." Some excerpts from participants' responses to the relevant question are as follows:

T98, F: "I think the teacher, who is also the owner of the website, should definitely upload videos of their lessons on the website. I believe listening leads to a more effective learning environment ..." T65, M: “On the website I designed, I put our classroom activities. Rather than direct instruction, I aimed to help students learn by 'traveling.' I added photos of the places we visited. I aimed to enable children to remember what they have learned when they look at these photos. In short, I put the places we visited and the activities we will do on the website ..." T21, F: "The website should, first of all, contain a description of the website and the topics it includes. Then, it should describe the units and learning outcomes ..."T12, M: "Information about all the disciplines that constitute the social studies course should be given ..." T35, F: "There should be a newsfeed to keep students informed of current events. Because most news websites are not suitable for children and do not broadcast special news for children ..." T25, F: "I designed a general education website, but I tried to focus on social studies-related learning outcomes. From the information that can be useful for students in real life to the learning outcomes related to history, geography, etc. We can add videos or learning activities of all kinds." T37, M: "The website should include all the units, topics, learning outcomes, etc. related to the lesson. Students should have the opportunity to revise the topics or watch the lesson videos whenever they want." T4, F: "The website should include a briefbackground and phone number or e-mail address of the founder of the website and a web page that describes the purpose of the website."

To sum up, according to the participants, websites designed for social studies teaching should include videos,

Table 7: Participants' Views about the Content to be included in Websites Designed for Social Studies Teaching

\begin{tabular}{llll}
\hline Theme & Codes & $f$ & $\%$ \\
\hline Content to be & Teaching Methods and Materials & 126 & 39.75 \\
included in & Social Studies-related Topics & 75 & 23.66 \\
Websites & Culture-related Topics & 53 & 16.72 \\
& Social Studies Course Curriculum & 43 & 13.56 \\
& Description of the Website & 20 & 6.31 \\
& Total & 317 & 100 \\
\hline
\end{tabular}


learning activities, images, the topics, content, disciplines, and definition of the social studies course, current events or information, current news, learning outcomes of the social studies course, brief background and phone number or e-mail address of the founder of the website, and a description of the purpose of the website.

\section{Participants' Views about the Features that Websites Designed for Social Studies Teaching should have}

As can be inferred from Table 8, according to the prospective teachers, "content features" (f:136), "content coverage" (f:49), "features that make students active" (f:27), and "formal features" (f:23) are the features that websites designed for social studies teaching should have. Accordingly, the most frequently stated feature was "content features." Some excerpts from participants' responses to the relevant question are as follows:

T2, M: “...I tried to make my website as fun as possible. I tried to ensure that my students can learn the topics without getting bored and I think I was able to do this." T44, F: "I tried to upload content that would arouse interest in my students, and I tried to upload content every day. Even though we lacked a classroom setting, I tried to add some classroom atmosphere to my website ..." T94, F: "I tried to take into account students' diverse needs, characteristics, etc. ..." T3, F: "I made sure that my website was suitable for the social studies course. I shared on my blog content related to the social studies course." T49, F: "...First of all, I included Atatürk on my website. I think we all owe something to Atatürk. For this reason, I aimed to raise awareness in students, too ..." T45, M: “...My favorite part of the website is the forums, and I think many students will like, too. Because this part allows students to chat freely with each other and with me about anything. Communication is very important for children. They need to express themselves in some way, by speaking or writing. I paid special attention to include a part where students can communicate." T48, M: "While designing my website, I paid the most attention to simplicity. I did my best to ensure that the website was well-organized so that everyone could easily find what they are looking for."

To sum up, the participants tried to make sure that their websites were fun and included activities that aroused interest in students and content that was suitable for students' level. They also reported having put on their websites social studies-

Table 8: Participants' Views about the Features that Websites Designed for Social Studies Teaching should have.

\begin{tabular}{llll}
\hline Theme & Codes & $f$ & $\%$ \\
\hline Features that & Content Features & 136 & 57.87 \\
Websites & Content Coverage & 49 & 20.85 \\
should have & Features That Make Students Active & 27 & 11.49 \\
& Formal Features & 23 & 9.79 \\
& Total & 235 & 100 \\
\hline
\end{tabular}

related content, information about M. Kemal Atatürk, and activities to promote teacher-student interaction. Lastly, they stated that they took care to ensure that their websites were well-organized and easy-to-use.

\section{Participants' Views about the Effects of Creating Websites for Social Studies Teaching}

As can be inferred from Table 9, effects of creating websites for social studies teaching include, according to the prospective teachers, "affective effects" (f:58), "effects on professional knowledge" (f:56), "effects on subject-matter knowledge" (f:40), and "effects on general culture knowledge" (f:22). Accordingly, the most frequently stated effects were "affective effects" and "effects on professional knowledge." Some excerpts from participants' responses to the relevant question are as follows:

T82, F: "While designing my website, I was very proud of feeling like a teacher and I had a lot of fun. At first, I had a hard time designing the website. But as I saw that I was able, I was happy. I felt like I was speaking to children as a helpful, responsible teacher. It has been an activity that I can consider doing in my future professional life... While researching for children, I also learned a lot. As I thought about what I could use around me, I realized that my thoughts and objects around me became meaningful." T49, F: "Designing a quality website is a really laborious task. I researched a lot when designing the website suitable for the target audience, and I had the opportunity to get to know my target audience better. While designing my website, I felt like a working teacher so I worked hard to ensure that my students could have fun learning. This, in turn, made me realize once again that I have chosen the right career..." T54, F: "Developing technology deeply affects education. We must always be open to innovations to achieve effective, modern education. It is important to be able to convey information to students in various ways. When doing so, the requirements of the lesson should be taken into account. Creating a website made me realize other teaching methods and that the technology was not that difficult to use in education. I will definitely use websites in my future professional life." T35, F: "...Regarding professional knowledge, I constantly asked myself questions such as, If I were a working teacher now, how could I help my students more and how could I contribute more to their learning?' As a result, it enabled me to produce ideas about what I should pay attention to or how I can improve myself in my future professional life...” T94, F: “...If I wish to create a website in my future professional life, I can use this experience..." T17, F: "Regarding its contributions to my subject-matter knowledge, first of all, I have learned a lot about the topic assigned to me and I am now much better at researching and collecting the right information..." T61, F: "This has been the first time I developed an educational website, and doing so has, above all, given me a great experience...” T46, F: “...I have learned a broad range of information sources while creating the website, and I have 
learned new definitions related to social sciences. I have also learned new general culture knowledge while I was researching current issues..."

To sum up, some of the effects of creating a website for social studies teaching include, according to the participants, making one happy, making one feel like a real working teacher, helping one keep up with the developing technology, helping one get ready for the teaching profession, contributing to one's subject-matter knowledge and research skills, helping one experience creating websites, and providing information on new information sources and current topics.

Participants' Views about the Alternatives to Websites Designed for Social Studies Teaching in Distance Education

As can be inferred from Table 10, the alternatives to websites designed for social studies teaching in distance education include, according to the prospective teachers, "live or recorded lessons" (f:63), "social media platforms" (f:58), "teaching methods and materials" (f:41), and "online education tools" (f:30). Accordingly, the most frequently stated alternatives were "live or recorded lessons" and "social media platforms." Some excerpts from participants' responses to the relevant question are as follows:

T15, F: "Websites are both up-to-date and can be used by everyone. Apart from websites, educational videos can be shared with students..." T44, F: "Alternatively, the Zoom platform can be used. Students can be asked to keep their cameras on during online lessons in order to ensure effective communication between students and teachers." T24, F: "Distance education can be provided through YouTube channels, as well. However, this method alone will not be as useful as websites. They can be more useful when they are used with websites." T78, M: "For example, we can use blogs where ideas about topics can be shared." T42, M: "Activities related to the learning outcomes of the social studies course can be held to increase students' levels of attention, motivation, and academic performance." T20, M: "...Video lessons can be shared with students via e-mail so that they can study on their own.” T46, F: “...Fun applications such as PowToon, Kahoot, and Quizlet can also be used for social studies lessons." T32, F: "Educational game websites aiming to teach social studies subjects can be used. Nevertheless, care should be taken to ensure that students join online classes in addition to using these websites."

Table 9: Effects of Creating Websites for Social Studies Teaching According to the Prospective Teachers.

\begin{tabular}{llll}
\hline Theme & Codes & $f$ & $\%$ \\
\hline Effects of & Affective Effects & 58 & 32.95 \\
Creating & Effects on Professional Knowledge & 56 & 31.82 \\
Websites & Effects on Subject-Matter Knowledge & 40 & 22.73 \\
& Effects on General Culture Knowledge & 22 & 12.50 \\
& Total & 176 & 100 \\
\hline
\end{tabular}

To sum up, the alternatives to websites designed for social studies teaching include, according to the participants, educational videos, Zoom, YouTube channels, blogs, educational activities, presentations, Kahoot!, educational game sites, PowToon, and Quizlet.

\section{Conclusion, Discussion, and Suggestions}

In this study, regarding the usage areas of websites in distance education, it was determined, based on participants' views, that websites could be used as a part of the learning-teaching process and as supportive educational tools. In a study interviewing prospective teachers, Karaca (2020) concluded that the Internet could be used because it is easily accessible, fast and because it provides alternative activities, rich content, and diverse teaching methods. Similarly, Baş and Tüzün (2007) found that online blogs, whose use in education has recently increased, were a suitable online educational setting during the transition to distance education, as well as providing convenience to both the designer and the user. Based on the participants 'views, the present study also determined that websites provided access to up-to-date information and contributed to teachers' professional competencies and social skills. Also, the participants thought that websites strengthened the communication between students and teachers, appealed to multiple senses, and enabled learning through experience.

Apart from the usage areas of websites in the general distance education process, using websites designed for social studies teaching in distance education can, according to the participants, contribute to the use of teaching methods and materials and thus to students. Also, the participants stated that using websites appropriate for the social studies curriculum could contribute to the development of social studies. Çetin and Günay (2011) emphasized that the availability of elements such as interactive activities, experiments, games, and animated videos on educational websites increased the interaction between students and teachers. Websites are considered important for social studies teaching, as they provide the opportunity to ensure that students have fun learning, and they provide easy access to many up-to-date videos, visuals, and technological elements in the digital environment. Similarly, Gülbahar (2005) found that it was important to

Table 10: Alternatives to Websites Designed for Social Studies Teaching in Distance Education According to the Prospective Teachers

\begin{tabular}{llll}
\hline Theme & Codes & $f$ & $\%$ \\
\hline Alternatives to & Live or Recorded Lessons & 63 & 32.81 \\
Websites & Social Media Platforms & 58 & 30.21 \\
& Teaching Methods and Materials & 41 & 21.35 \\
& Online Education Tools & 30 & 15.63 \\
& Total & 192 & 100 \\
\hline
\end{tabular}


offer multimedia teaching materials on educational websites and include various information sources to enrich the content. Indeed, websites can contribute significantly to social studies teaching by providing online museum tours or by including videos of experiments, social situations, etc.

Regarding the advantages of using websites in social studies teaching, the participants of the present study noted that proper use of websites in social studies education could ensure effective learning, provide easy access to information, and improve student motivation. They also stated that it would help students gain knowledge, skills, and attitudes, ensure that they have fun learning, and contribute to integrating technology into education. Uçar (2016) found that students' motivation increased with the use of motivation strategiesmethods in the distance education process. It is, therefore, critical for prospective teachers to integrate technology into education with their own teaching methods, which will contribute significantly to students, to their future co-workers, and eventually to the education community as a whole (Shaltry et al., 2013). Emphasizing the benefits of websites for the inclusion of technology into the education process, the prospective teachers underlined the importance of an effective social studies education supported by technology.

Apart from the many advantages that distance education offers, there are also some drawbacks (Vlachopoulos, 2020; Korucu \& Sezer, 2016). Likewise, the social studies teaching provided through websites has disadvantages for certain reasons. The participants of the current study stated that using websites in education could cause negative consequences due to reasons such as reducing active participation in the learning process and lack of equality of opportunity in education arising from the fact that not every student has Internet access, tablets, computers, etc. Lending support to this finding, Balaman and Hanbay Tiryaki (2021) and Bennett, Uink and Cross (2020) emphasized the importance of reaching all students in distance education, developing technical infrastructures, and bringing access to software and hardware to a sufficient level. In addition, it was emphasized by the prospective teachers that classroom management in online education has certain challenges compared to face-to-face education and that it might be difficult to manage certain types of students who need extra supervision. The prospective teachers stated that the Internet's controlled and conscious use would enable the effective use of the Internet in social studies teaching (Karaca, 2020). Despite all the negative aspects of distance education and the elements involved in this process, activities that can be used in both theoretical and practical lessons in teacher training can bring about numerous positive developments (Gelişli, 2015).

It has been stated in the literature that educational websites should be designed specifically for educational goals (Kobzhanova, 2020). Indeed, the present study participants also stated that websites designed for social studies teaching should include various teaching methods, course-related materials, social studies-related topics, culture-related topics, and supportive videos, images, and information about current issues and news reports. Moreover, prospective teachers noted that the content of websites designed for social studies teaching should be ensured to arouse students' interest and help them have fun learning. They also believed that websites should include information about Mustafa Kemal Atatürk and should be easy-to-use and well-organized.

On the other hand, creating websites for social studies teaching both had affective effects on prospective teachers and contributed significantly to their professional knowledge. They stated that the process made them "feel like a real working teacher" and contributed to their subject-matter knowledge. Moreover, the experience of creating websites helped them become aware of new information sources, which, according to them, contributed to both their general culture knowledge and research skills. In a study creating a website including webbased lessons, tests, chat rooms, and other web media, Chandra and Lloyd (2008) concluded that web technologies positively affected learning outcomes. According to the participants, applications such as Zoom, Kahoot, PowToon, or Quizlet, or web blogs can be used as alternatives to websites. In their study investigating prospective teachers' views, Özer and Albayrak Özer (2017) found that digital tools had advantages such as saving time, improving collaboration among students, providing fast access to information, and strengthening research skills, as well as improving students' motivation and interest in the course.

As a result of research; concludes that websites are a part of the learning-teaching process, that it is important to use websites as educational tools, that websites enable technology to be integrated into education, that websites enable including up-to-date content for effective teaching of social studies, and that websites provide students with easy access to knowledge through fun learning environments. Undoubtedly, it is aimed to use the technology, which is actively used in almost all areas of life, for educational activities, as well. Firstly, to achieve this goal, both working and prospective teachers must be equipped with the skills and competencies to use these technologies (Karakuş \& Er, 2021; Yavuz-Konokman et al., 2013). On the other hand, the prospective teachers who participated in this study mentioned certain disadvantages of using websites for educational purposes arising from causes that are not actually hard to eliminate (lack of Internet access, computers, tablets, etc.). The most significant result of this study is that websites are generally effective learning-teaching settings, providing students with interactive learning opportunities for social studies education.

Based on the results, it can be recommended that the creation and use of websites for the social studies course 
should be promoted among both working and prospective teachers, that both working and prospective teachers can have their own educational websites with up-to-date and rich content, and that the effectiveness of social studies teaching can be increased by means of interactive teaching materials to be included on the websites. Given the considerable amount of time that students spend online, ensuring that they spend some of it on educational websites that contain informative, up-to-date, and fun content that arouses interest in them can produce positive outcomes.

\section{References}

Akar, H. (2019). Durum çalışması. A. Saban \& A. Ersoy (Ed.), Eğitimde nitel araştırma desenleri içinde (s. 139-177). Ankara: Anı Yayıncılı.

Aytan, T., \& Başal, A. (2015). Türkçe öğretmen adaylarının web 2.0 araçlarına yönelik algılarının incelenmesi. Turkish Studies (Elektronik), 10(7), 149-166.

Balaman, F., \& Hanbay Tiryaki, S. (2021). Corona Virüs (Covid19) nedeniyle mecburi yürütülen uzaktan eğitim hakkında öğretmen görüşleri. İnsan ve Toplum Bilimleri Araştırmaları Dergisi, 10(1), 52-84.

Baltaci-Goktalay, S., \& Ozdilek, Z. (2010). Pre-service teachers' perceptions about Web 2.0 technologies. Procedia-Social and Behavioral Sciences, 2(2), 4737-4741.

Baş, T., \& Tüzün, H. (2007). Aday öğretmenlerin alan eğitiminde web günlüklerinin (blog'ların) kullanılması. Uluslararası Öğretmen Yetiştirme Politikaları ve Sorunları Konferansı Bildiriler Kitabı içinde (s. 34-38). Bakü, Azerbaycan.

Bennett, R., Uink, B., \& Cross, S. (2020). Beyond the social: Cumulative implications of COVID-19 for first nations university students in Australia. Social Sciences \& Humanities Open, 2 (1), 1-5.

Chandra, V., \& Lloyd, M. (2008). The methodological nettle: ICT and student achievement. British Journal of Educational Technology, 39, 1087-1098.

Chick, R. C., Clifton, G. T., Peace, K. M., Propper, B. W., Hale, D. F., Alseidi, A. A., \& Vreeland, T. J. (2020). Using technology to maintain the education of residents during the COVID-19 pandemic. Journal of Surgical Education, 77(4), 729-732.

Curry, K., \& Cherner, T. (2016). Social studies in the modern era: A case study of effective teachers' use of literacy and technology. The Social Studies, 107(4), 123-136.

Çetin, O., \& Günay, Y. (2011). Fen eğitimine yönelik örnek bir web tabanlı öğretim materyalinin hazırlanması ve bu materyalin öğretmen öğrenci görüşleri doğrultusunda değerlendirilmesi. Ahi Evran Üniversitesi Eğitim Fakültesi Dergisi, 12 (2), 175-202.

Debele, M., \& Plevyak, L. (2012). Conditions for successful use of technology in social studies classrooms. Computers in the Schools, 29(3), 285-299.

Demirezen, S., \& Keleş, H. (2020). Sosyal bilgiler öğretmenlerinin teknopedagojik alan bilgisi yeterliliklerinin çeşitli değişkenlere göre incelenmesi. Uluslararası Sosyal Bilgilerde Yeni Yaklaşımlar Dergisi, 4(1), 131-150.

Dere, İ., \& Ateş, Y. (2020). Sosyal bilgiler derslerinde teknolojik araç ve materyal kullanımı: Bir durum çalışması. Erzincan Üniversitesi Eğitim Fakültesi Dergisi, 22(2), 496-514.
Elmas, R., \& Geban, Ö. (2012). Web 2.0 tools for 21st century teachers. International Online Journal of Educational Sciences, 4(1), 243-254.

Firat, E. A., \& Köksal, M. S. (2017). The relationship between use of web 2.0 tools by prospective science teachers and their biotechnology literacy. Computers in Human Behavior, 70, 44-50.

Filiz, M., Arslan, S., \& Coştu, S. (2008). Matematik eğitimi içerikli web sitesi tasarımına ait akademisyen, öğretmen ve öğrenci görüşleri. Uluslararası Eğitim Teknolojileri Konferansı, Eskişehir.

Gelişli, Y. (2015). Uzaktan eğitimde öğretmen yetiştirme uygulamaları: Tarihçe ve gelişim. Journal of Research in Education and Teaching, 4 (3), 313-321.

Germann, T. C., Gao, H., Gambhir, M., Plummer, A., Biggerstaff, M., Reed, C., \& Uzicanin, A. (2019). School dismissal as a pandemic influenza response: When, where and for how long?. Epidemics, 28, 100348.

Gülbahar, Y. (2005). Web-destekli öğretim ortamında bireysel tercihler. The Turkish Online Journal of Educational Technology - TOJET, 4 (2), 76-82.

Horzum, M. B. (2007). Web tabanlı yeni öğretim teknolojileri: Web 2.0 araçları. Eğitim Bilimleri ve Uygulama, 6(12), 99-121.

Karaca, İ. N. (2020). Sosyal bilgiler öğretmen adaylarının algılarına göre kitle iletişim araçlarının sosyal bilgiler öğretiminde kullanımı. Unpublished master's thesis, İnönü Üniversitesi Eğitim Bilimleri Enstitüsü: Malatya.

Karakuş, N., \& Er, Z. (2021). Türkçe öğretmeni adaylarının web 2.0 araçlarının kullanımıyla ilgili görüşleri. IBAD Sosyal Bilimler Dergisi, (9), 177-197.

Karatepe, F., Küçükgençay, N., \& Peker, B. (2020). Öğretmen adayları senkron uzaktan eğitime nasıl bakıyor? Bir anket çalışması. Journal of Social and Humanities Sciences Research, 7(53), 1262-1274.

Keskin, M., \& Özer Kaya, D. (2020). COVID-19 sürecinde öğrencilerin web tabanlı uzaktan eğitime yönelik geri bildirimlerinin değerlendirilmesi. İzmir Kâtip Çelebi Üniversitesi Sağlık Bilimleri Fakültesi Dergisi, 5(2), 59-67.

Kobzhanova, A. E. (2020). From the experience of using educational internet resources in teaching English. Педагогическая наука и практика, 3(29).

Korucu, A., \& Sezer, C. (2016). Web 2.0 teknolojilerini kullanma sıklığının ders başarısı üzerindeki etkisine yönelik öğretmen görüşleri. Eğitim ve Öğretim Araştırmaları Dergisi, 5 (2), 379-394.

Miles, M. B. \& Huberman, A. M. (2016). Nitel veri analizi (S. Akbaba Altun \& A. Ersoy, Çev. Ed.). Ankara: Pegem Akademi.

NCSS (2013). Technology position statement and guidelines. Retrieved October 21, 2020, from http://www.socialstudies. org/positions/technology

OECD (2009). Creating Effective Teaching and Learning Environments. First Results from TALIS. Paris: OECD Publications. Retrieved August 8, 2020, from http://www.oecd. org/dataoecd/17/51/43023606.pdf

Özer, Ü., \& Albayrak Özer, E. (2017). Sosyal bilgiler ile bilgisayar ve öğretim teknolojileri öğretmeni adaylarının eğitimde web 2.0 kullanımına yönelik görüşleri. 3nd International Congress on Political, Economic and Social Studies (ICPESS).

Özerbaş, M. A., \& Akın Mart, Ö. (2017). İngilizce öğretmen adaylarının web 2.0 kullanımına ilişkin görüş ve kullanım 
düzeyleri. Ahi Evran Üniversitesi Kırşehir Eğitim Fakültesi Dergisi, 18(3), 1152-1167.

Prensky, M. (2001). Digital natives, digital immigrants part 2: Do they really think differently?. On the horizon.

Shaltry, C., Henriksen, D., Wu, M. L., \& Dickson, W. P. (2013). Situated learning with online portfolios, classroom websites and Facebook. TechTrends, 57(3), 20-25. DOİ: http://dx.doi. org.ezproxy.uky.edu/10.1007/s11528-013-0658-9.

Shriner, M., Clark, D. A., Nail, M., Schlee, B. M., \& Libler, R. (2010). Social studies instruction: Changing teacher confidence in classrooms enhanced by technology. The Social Studies, 101(2), 37-45.

Tatlı, Z., İpek-Akbulut, H., \& Altınışık, D. (2016). The impact of web 2.0 tools on pre-service teachers' self confidence levels about TPCK. Turkish Journal of Computer and Mathematics Education, 7(3), 659-678.

Tavşancıl, E., \& Aslan, E. (2001). Sözel, yazılı ve diğer materyaller için içerik analizi ve uygulama örnekleri. İstanbul: Epsilon Yayınları.

Telli, S. G., \& Altun, D. (2020). Coronavirüs ve çevrimiçi (online) eğitimin önlenemeyen yükselişi. Üniversite Araştırmaları Dergisi, 3(1), 25-34.

Uçar, H. (2016). Uzaktan eğitimde motivasyon stratejilerinin öğrenenlerin ilgileri, motivasyonları, eylem yeterlikleri ve başarıları üzerine etkisi. Unpublished doctorate dissertation, Sosyal Bilimler Enstitüsü: Eskişehir.
UNESCO. (2020). COVID-19 Educational Disruption and Response. Retrieved June 26, 2020, from https://en.unesco.org/covid19/ educationresponse

Vlachopoulos, D. (2020). COVID-19: Threat or opportunity for online education? Higher Learning Research Communication, 10(1), 16-19. DOI: 10.18870/hlrc.v10i1.1179.

WHO. World Health Organizations (WHO) announces COVID19 outbreak a pandemic. (2020). Retrieved June 4, 2020, from http://www.euro.who.int/en/health-topics/healthemergencies/coronavirus-covid-19/news/news/2020/3/whoannounces-covid-19-outbreak-a-pandemic

Wright, V. H., \& Wilson, E. K. (2009). using technology in the social studies classroom: The journey of two teachers. The Journal of Social Studies Research, 33(2), 133-154.

Yavuz Konokman, G., Yanpar Yelken, T., \& Sancar Tokmak, H. (2013). Sınıf öğretmeni adaylarının TPAB'lerine ilişkin algılarının çeşitli değişkenlere göre incelenmesi: Mersin Üniversitesi örneği. Kastamonu Eğitim Dergisi, 21(2), 665-684.

Yaylak, E., \& İnan, S. (2018). Sosyal bilgiler öğretmenlerinin eğitimde sosyal medyanın kullanılmasına yönelik görüşlerinin incelenmesi. Türkiye Bilimsel Araştırmalar Dergisi, 3(1), 1-32.

Yıldırım, A., \& Şimşek, H. (2011). Sosyal bilimlerde nitel araştırma yöntemleri. Ankara: Seçkin Yayıncılık.

Yin, R. K. (2017). Durum çalışması araştırması uygulamaları (İ. Günbayı, Çev.). Ankara: Nobel. 